\title{
Predicting Depth of Mineral Deposit using Gravity-Density Downward Correlation by Fourier Transform
}

\author{
(C) E. E. Epuh, J. B. Olaleye, O. G. Omogunloye, 2016 \\ Department of Surveying and Geoinformatics, University of Lagos, \\ Lagos, Nigeria
}

Received June 15, 2016

Presented by the Editorial Board Member V. I. Starostenko

\begin{abstract}
Залишкові гравітаційні аномалії є суперпозицію ефектів від декількох приповерхневих кордонів. Визначити перерахунком гравітаційних аномалій вниз глибину конкретної структури, яка обумовлює інтегральну величину залишкових гравітаційних аномалій, можна, тільки використовуючи додаткові приповерхневі дані, наприклад щільнісного каротажу. У цій статті він застосований для визначення функції розподілу зваженої щільності, виділення декількох шарів і кореляції щільності з гравітаційним полем, перерахованим вниз. На основі цих даних виконано прогноз глибини корисних копалин за допомогою перетворення Фур'є. Результати показують, що перерахована вниз залишкова гравітаційна аномалія на глибину 2015-2170 м описує всі її особливості, які чітко спостерігаються на площині спостережень, а також демонструють міні-мальне спотворення форми аномалій. Аномальна маса залягає в межах цих глибин. Глибини, отримані перерахунком вниз гравітаційного поля, були зрівняні з глибинами за даними сейсміч-них спостережень методом відбитих хвиль в районі досліджень. Відносна помилка становила 1,37 і 0,46 \% відповідно.
\end{abstract}

Ключові слова: ізостатична залишкова гравітаційна аномалія, перерахунок вниз, щільнісний каротаж, загасання, функція зваженої щільності.

Introduction. The downward continuation operation of potential field data is a kernel operation for many potential field data processing/interpretation techniques and inversion methods. These analytic continuations lead to convolution integrals that can be solved either in the space or the frequency domain. The earliest attempts were done in the space domain by deriving a set of weights that, when convolved with field data, yielded approximately the desired transform [Peters, 1949; Henderson, 1960; Byerly, 1965]. Fuller [1967] developed a rigorous approach to determine the required weights and to analyses their performance. The space-domain operators were soon replaced by frequency-domain operators. Dean [1958] was the first to recognize the utility of using Fourier transform techniques in performing analytic continuations. Mesko [1965] and Clarke [1969] contributed to the understanding of such transforms, which now are carried out routinely. Whereas upward continuation is a very stable operation, the opposite is true for downward continuation, where special techniques, including filter response tapering and regularization, must be applied to control noise. Standard Fourier filtering techniques only permit analytic continuation from one level surface to another. To overcome this limitation, Grant and West [1987] introduced the integration of density log in the delineation of the multiple interfaces using a weighting density function. However, the minimization of the attenuation value in the weighting density function is critical and has not obtained a steady mathematical formulation. Based on the weighting density idea, we present an improved model in wave number domain.

Physics of the Problem. In this process adopted in the minimization of the attenuation is based upon the concept of equivalent stratum. Equivalent stratum strategy is the process in which observed gravity field distribution at the surface can be related to the equivalent distribution of density on that pla- 
ne [Grant, West, 1987]. This is particularly relevant when an interface between two layers having different densities has been identified at some known or estimated depth by means of density well logging. This process is always difficult to interpret because of inherent uncertainties in the location and size of the structure causing the gravity anomaly at the observation point. However, residual gravity anomaly is caused by the anomalous masses lying between surface of observation and the desired depth of projection, and causing fluctuation in the gravity values at intermediate levels [Grant, West, 1987; Dobrin, Savit, 1988]. In downward continuation, an important aspect of the underlying theory is that when the field is continued too close to the depth of the anomalous mass, oscillations set in due to the instability of the field at points closer to the source anomaly arising from the inverse relationship between the anomalous mass and the distance from the observation point. As the distance becomes smaller, the anomaly is exponentially amplified and unstable. It becomes stabilized within the horizon of the anomalous mass and oscillation and divergence re-appears when the projected field is beyond the horizon of the anomalous mass. Once a source is detected within the region of continuity, the process is terminated. This identified depths mark the horizon of the anomalous mass. The difficulties posed in the interpretation of the downward continued data are resolved with the aid of additional subsurface data. In this research, observed density profile (density log) was utilized in the downward continuation of the residual gravity anomaly.

In the use of density log, the determination of the weighting density function is very important. In this case, the attenuation is required to be made as small as practicable such that the weighting density variation is minimized. This helps in the presentation of a plausible subsurface structure of the ba$\sin$ from the projected fields. The minimization of the weight variation is accomplished in this research by establishing a mathematical model which relates the weight attenuation as a function of (1) the wave numbers (2) the gravity station spacing and (3) the depth of projection using the concept of equivalent stratum.

In this paper, by viewing the downward continuation of potential field as an inverse problem of upward continuation using Fourier transform, a convolution type linear integral equation for downward con-

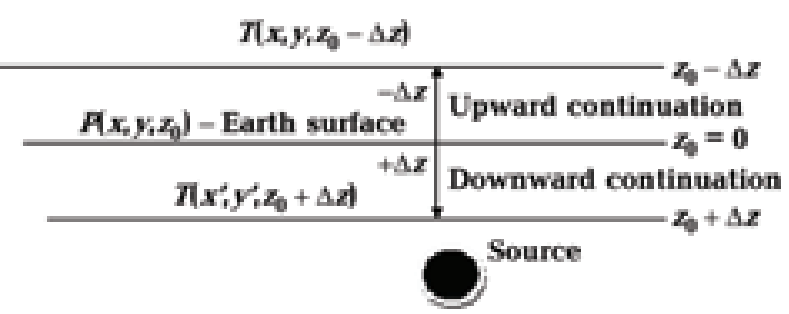

Fig. 1. Location of observation surface, upward continuation surface $T$ and downward continuation surface $T^{\prime}$. tinuation was obtained. Upward Continuation transforms the potential field measured on one surface to the field that would be measured on another surface farther from all sources. Fig. 1 shows the Location of observation surface $P$, upward continuation surface $T$ and downward continuation surface $T^{\prime}$

It is known that in spatial domain potential field data $V\left(x_{T}, y_{T},-\Delta \mathrm{z}\right)$ and $V\left(x_{p}, y_{p}, z_{0}\right)$ has relationship as follows:

$$
V\left(x_{T}, y_{T}, z_{0}-\Delta z\right)=\frac{-\Delta z}{2 \pi} \int_{-\infty-\infty}^{\infty} \int_{-\infty}^{\infty} \frac{V\left(x_{p}, y_{p}, z_{0}\right)}{\left[\left(x_{T}-x_{p}\right)^{2}+\left(y_{T}-y_{p}\right)^{2}+\Delta z^{2}\right]^{3 / 2}} d x_{p} d y_{p},
$$

$\Delta z>0$

where $V\left(x_{p}, y_{p}, z_{0}\right)$ denotes potential field data on the observed plane at altitude $z_{0}=0$. Equations (1) $V\left(x_{T}, y_{T}, z_{0}-z\right)$ denotes potential field data on the target plane an upward continuation integral. It shows how to calculate the value of potential field at any point $T$ above a level horizontal surface from complete knowledge of the field on the surface. Equation (1) is a two-dimensional convolution.

$$
V\left(x_{T}, y_{T}, z_{0}-\Delta z\right)=\int_{-\infty}^{\infty} \int_{-\infty}^{\infty} V\left(x_{p}, y_{p}, z_{0}\right) \psi_{u}(x, y, \Delta z) d x_{p} d y_{p},
$$




$$
\begin{gathered}
\psi_{u}(x, y, \Delta z)=\frac{\Delta z}{2 \pi} \frac{1}{\left[\left(x_{T}-x_{p}\right)^{2}+\left(y_{T}-y_{p}\right)^{2}+\Delta z^{2}\right]^{3 / 2}}, \\
\psi_{u}(x, y, \Delta z)=-\frac{1}{2 \pi} \frac{\partial}{\partial \Delta z} \frac{1}{r}
\end{gathered}
$$

where $r=\sqrt{\left(x_{T}-x_{p}\right)^{2}+\left(y_{T}-y_{p}\right)^{2}+\Delta z^{2}}$.

The Fourier transform of equation (2) obtained with respect to Equation (4) is given as

$$
F\left[\psi_{u}\right]=-\frac{1}{2} \frac{\partial}{\partial \Delta z} F[x, y]
$$

with respect to equation (2), the Fourier transform of equation (5) is given as

$$
\begin{gathered}
F\left[\psi_{u}\right]=-\frac{\partial}{\partial \Delta z} \frac{e^{-u \Delta z}}{u} \\
F\left[\psi_{u}\right]=e^{-u \Delta z},|\Delta z|>0 \quad \text { (Fourier kemel) }
\end{gathered}
$$

let $V\left(x_{T}, y_{T}, z_{0}-\Delta \mathrm{z}\right)=V_{\text {up }}, V\left(x_{p}, y_{p}, z_{0}\right)=V, \psi_{u}\left(x, y_{1} \Delta \mathrm{z}\right)=\psi_{\text {up }}$.

Equation (2) can be rewritten as

$$
V_{\text {up }}=V^{*} \psi_{\text {up }}
$$

where * denotes convolution operation.

Applying Fourier transform to $V_{\text {up }}, V, \psi$ up respectively, we obtain [Blakely, 1996]

$$
F\left[V_{\text {up }}\right]=F|V| F\left[\psi_{\text {up }}\right],
$$

where $F\left[V_{\text {up }}\right.$ ] - Fourier transform of the upward field, $F|V|$-Fourier transform of the observed residual gravity $\Delta g$ field at $z_{0}=0 . F|V|$ is the measurement observed on the Earth surface. Given $F|V|$, upward continuation to height $\Delta z$ is obtained by multiplying $F|V|$ by the Fourier kernel:

$$
\begin{gathered}
F\left[V_{\text {up }}\right]=\Delta \hat{g} e^{-u \Delta z}, \\
\Delta \bar{g}(x, y)_{\text {up }}=\Delta \hat{g} e^{-u \Delta z} .
\end{gathered}
$$

$\Delta g$ is the residual gravity value at the surface, $\Delta \overline{\mathrm{g}}(x, y)$ - upward continued field.

Downward Continuation Model Formulation. The calculation of downward continuation is very useful in the interpretation of potential field. This is obtained by writing the inverse Fourier Transform of Equation (11):

$$
\begin{gathered}
F\left[V_{\text {down }}\right]=F|V| F^{-1}\left[\psi_{\text {up }}\right], \quad F\left[V_{\text {down }}\right]-\text { downward continued residual field, } \\
\Delta \bar{g}(x, y)_{\text {down }}=\frac{1}{2 \pi} \Delta \hat{g} e^{+u \Delta z}
\end{gathered}
$$

where $\Delta \bar{g}(x, y)_{\text {down }}$ is the residual gravity value at depth $\Delta z$. 
The Use of Density Logs in Downward Continuation. Density log is a well log that records formation density. The density tool senses formation density by measuring the attenuation of gamma rays between a source and a detector. In density log observation, the gamma rays emitted continuously by the source are channeled into the formation. There they undergo multiple collisions with the electrons that cause them to lose energy and scatter in all directions by a mechanism called Compton scattering. Compton scattering depends only on the electron density of the formation which is closely related to bulk density. When their energies drop below $0.1 \mathrm{mev}$, the gamma rays die by a process called photoelectric absorption. Photoelectric absorption depends on both electron density and the average atomic number of the material making up the formation. This mechanism is utilized by litho-density tool to indicate rock type.

The major ambiguity in the determination of the subsurface structures by the use of downward continuation is due to the existence of multiple interfaces. Indeed, the complex nature of the density logs obtained from boreholes makes it seem highly probable that in most cases, residual anomalies are the superposition of effects originating from several interfaces at once. With some modifications and under certain conditions, the method of downward continuation can then be extended to include general density-depth relationship such as those found on well-logging methods.

In a sedimentary basin, the density varies with depth because of compaction of the sediments. Let the density of the sediments between the surface

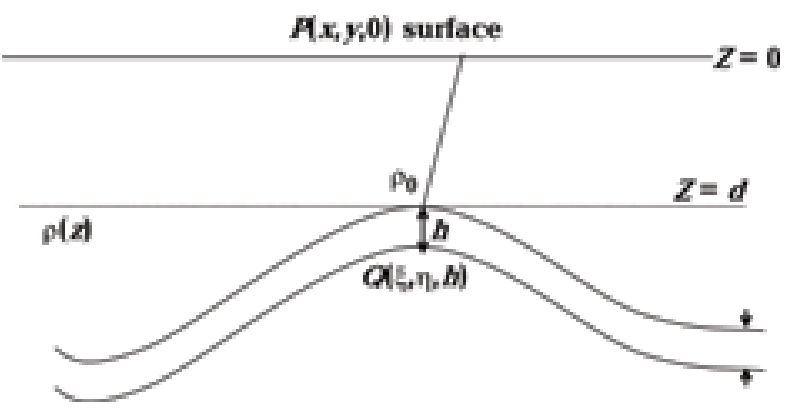

Fig. 2. Downward continuation when a continuous density log is available [Grant, West, 1987]. $z=0$ and the depth $d$ (initial logging depth) be given as $\rho_{0}$. This formula can be explained by referring to Fig. 2 . The density contrast between the surface and the density at depth

$$
z_{n}=d+\sum_{i=1}^{n} h_{i}
$$

be given as

$$
\Delta \rho_{n}=\rho_{n}-\rho_{0},
$$

where $\Delta \rho_{n}$ is the density contrast at depth $z_{n}, \rho_{n}$ - formation density of the formation $n$.

The density contrast decreases exponentially with depth according to the equation

$$
X(\gamma)=\Delta \rho_{n} e^{\gamma z_{n}},
$$

where $X(g)$ - weighting density function, $z_{n}$ - depth below the surface, $g$ - attenuation.

The horizontal dimensions of the basin are much larger than its depth, so the shape of the basin can be approximated as an infinite slab.

By introducing the Equation 15 into Equation 13, the downward continuation (DC) is expressed as

$$
\Delta \bar{g}(x, y)_{Z_{n}}=\frac{1}{2 \pi} X(\gamma) \Delta \hat{g}(x, y),
$$

where $\Delta \overline{\mathrm{g}}(x, y)_{Z_{n}}$ is the residual gravity anomaly value at depth $Z_{n}, \Delta g$ is the residual gravity value at the surface $(z=0)$.

The attenuation $g$ must be as small as practicable to avoid reading more information than is actually there. In this, $g$ is computed using the weighting distribution as applied to equivalent stratum. The weighting distribution is given as

$$
Q(x, y)=r\left(2 d \sqrt{u \gamma^{2}}\right)^{-1},
$$

where $Q(x, y)$ - weighting distribution, $r=2 \sqrt{\gamma w}, d$ - initial logging depth, $w=u s, u$ - wave number, $s$ - shot point spacing, $g$ - attenuation. 
Introducing the concept of equivalent stratum into equation (17), we obtain

$$
Q_{E}(x, y)=\rho(x, y) r\left(2 d \sqrt{u \gamma^{2}}\right)^{-1}
$$

In DC, the short wavelength contribution to $\Delta g$ must be taken out of the spectrum to obtain a minimum attenuation. The short wavelength with respect to its equivalent stratum is expressed as

$$
Q_{S}(x, y)=\rho(x, y) w^{-1 / 2} \text {. }
$$

By eliminating the short wavelength, we obtain

$$
Q(x, y)=Q_{E}(x, y)-Q_{S}(x, y)=\rho(x, y) r\left(2 d \sqrt{u \gamma^{2}}\right)^{-1}-\rho(x, y) w^{-1 / 2} \text {. }
$$

Differentiating equation (20) with respect to density and equate to zero to obtain the minimum $g$

$$
\frac{d Q}{d \rho}=\frac{r}{2 d \sqrt{u \gamma^{2}}}-\frac{1}{w^{1 / 2}}=0 .
$$

The final expression for the attenuation $g$ is given as

$$
\begin{gathered}
\gamma=\frac{s^{2}}{d^{2}} \sqrt{u_{x}^{2}+u_{y}^{2}} \\
\Delta \bar{g}(x, y)_{d}=\frac{1}{2 \pi} \Delta \hat{g}(x, y) \Delta \rho_{n} e^{\frac{s^{2}}{d^{2}} \sqrt{u_{x}^{2}+u_{y}^{2}} z_{n}}
\end{gathered}
$$

where $u=\sqrt{u_{x}^{2}+u_{y}^{2}}, u_{x}=\frac{\pi}{x_{m}}, u_{y}=\frac{\pi}{y_{m}}, u_{x}, u_{y}$ - wave numbers, $s$ - distance between stations, $d$ - initial chosen depth from the log we choose $x$ and $y$ axes which lie in the directions of maximum and minimum horizontal gradient in $\Delta g$, $x_{m}$ and $y_{m}$ - measured distances bet-

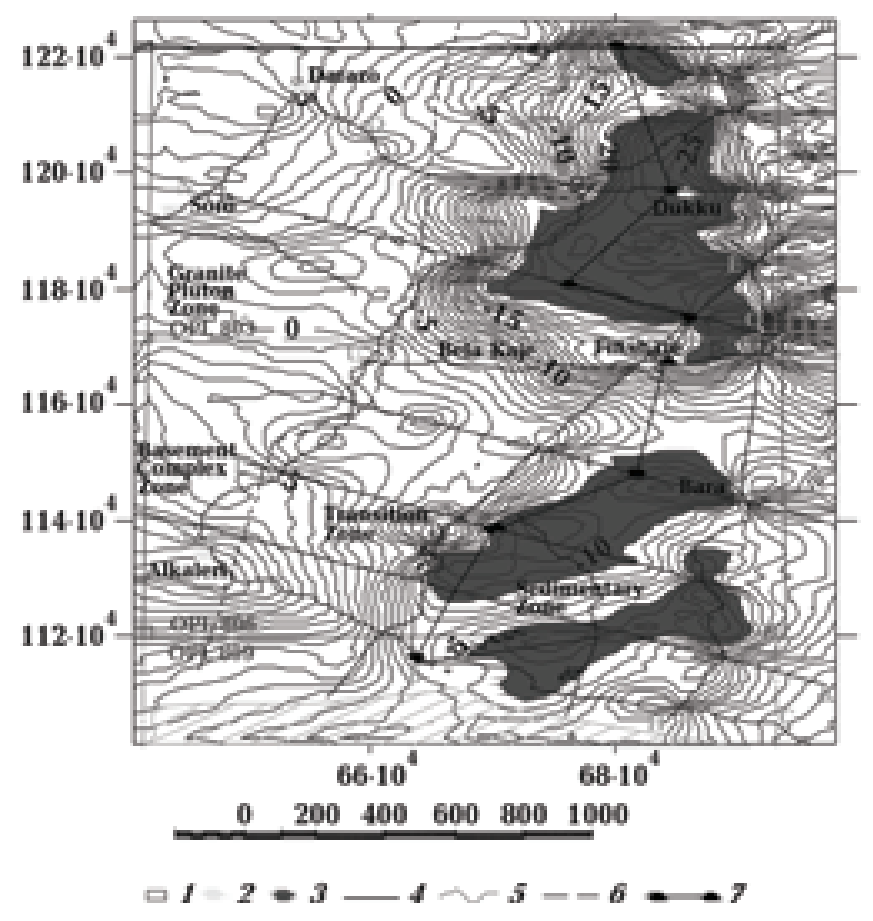

N lue $1 / 2 \Delta g_{\max }$ in these two directions, $4 \Delta g_{\max }$ - amplitude of the residual anomaly on the surface of the ground.

Equation (15) shows that as we move towards the anomaly source, all wave numbers are attenuated by $e^{g z_{n}}$ and that the highest wave numbers ( shortest wavelengths) are attenuated most rapidly. The density contrast defines the basement control over the anomalous mass.

Methodology. The gravitational data for this investigation is a set of Bouguer gravity and isostatic residual gravity ano-

$\rightarrow$ Fig. 3. Isostatic residual gravity anomaly map using Pratt-Hayford model C.I (1 mGal): 1 - opl vertex, 2 - gravity base station, 3 contour closures, $4-$ gravity lines, 5 - contour lines, 6 - transition zone boundary, 7 - fault lines. 


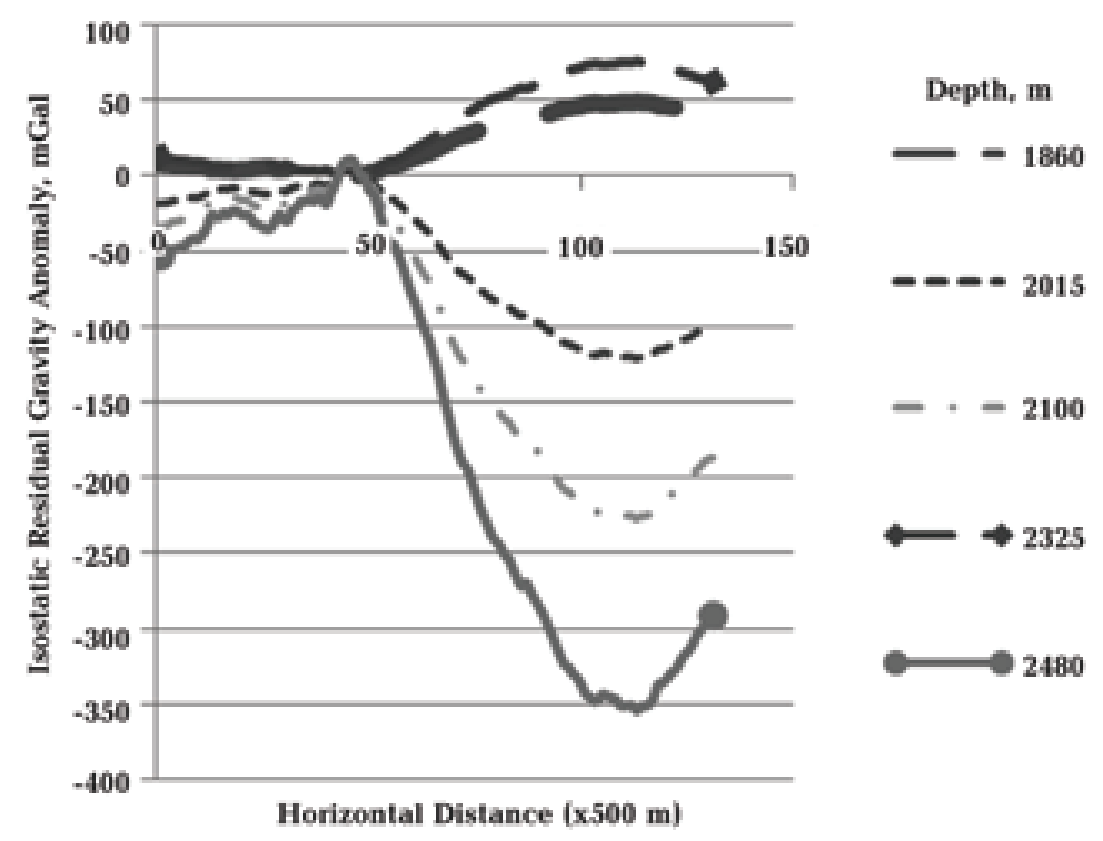

Fig. 4. Downward continuation profile for line 94D039.

malies at 1813 stations in Gongola basin, North-Eastern Nigeria. The Bouguer gravity anomaly was computed using the crustal density of $2.67 \mathrm{~g} / \mathrm{cm}^{3}$. The Pratt-Hayford isostatic model (spherical approximation) was used in the determination of the isostatic regional anomaly. The isostatic residual anomalies were calculated by adding the isostatic regional anomalies to the Bouguer gravity anomalies. In the downward continuation process, the depth interval for density observation is given as $155 \mathrm{~m}$, while $d$, the initial chosen density log formation depth is given $1705 \mathrm{~m}$.

In the application of the seismic reflection data for downward depth validation, seven horizons were picked from the seismic sections for structural mapping and evaluation of the Gongola basin to determine the prospect level and the structural viability of the basin. The horizons include the following: H1, H2, H3, H4, H5, H6 and the top basement. Fig. 4 (line 806-97-D-036) shows which also contains the prospect horizon The time values obtained from the seismic sections were used to obtain the depth estimate using the checkshot curve. The seismic section was also calibrated using the checkshot curve. The depth structure map for the prospect horizon (H4) is shown in Fig. 5.

Results and Discussion. Results. Fig. 4 shows a profile of the isostatic residual gravity anomaly variations at the various observed depths. The profiles show that the horizon for the stabilization of the projected residual field was achieved at the depth of $2015 \mathrm{~m}$ and $2170 \mathrm{~m}$ respectively. The anomalous mass lies within these depths. Fig. 5 shows the projected field at various depths reflecting the residual gravity anomaly field structure within the horizon.

Discussion. The projected isostatic residual anomaly field should reflect the pattern of the field observed at the surface.

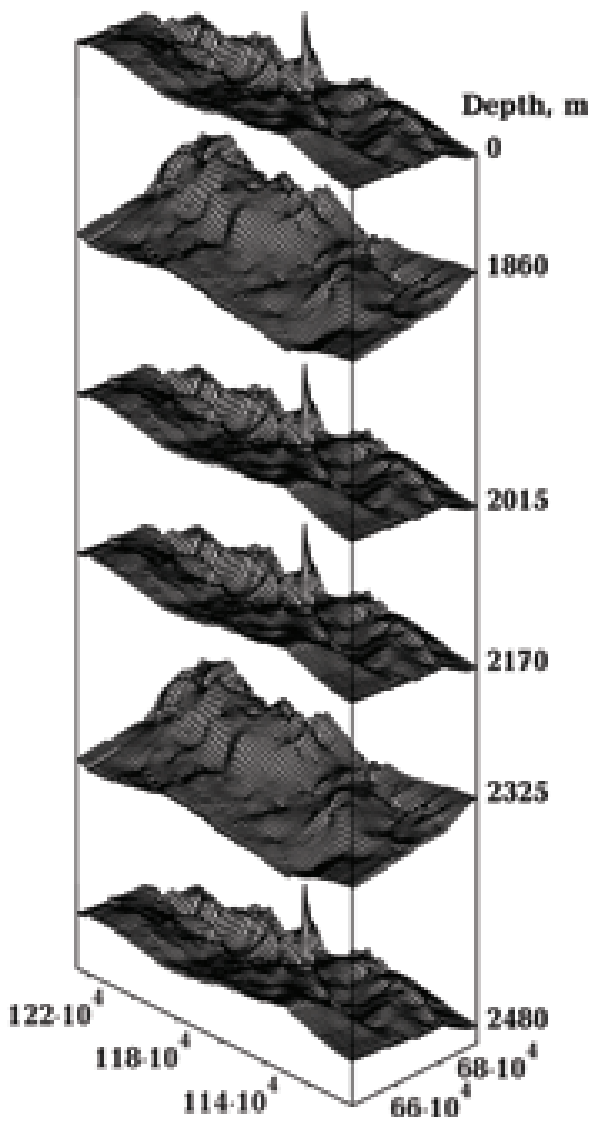

Fig. 5. Downward continuation maps at various depths $(Z=0,1860 \mathrm{~m}, 2015 \mathrm{~m}$, $2170 \mathrm{~m}, 2480 \mathrm{~m})$. 
From Fig. 5, it is observed that at depth $1860 \mathrm{~m}$, the pattern of the residual gravity anomaly is at variance with that obtained at the surface. The residual gravity anomaly contains positive values in the sedimentary zone of the project area. This does not conform to the geology of the basin as indicated by the residual gravity anomaly observed at the surface. At depth $2015 \mathrm{~m}$, the pattern of the residual gravity anomaly reflects that one which was observed at the surface. This depth marks the upper horizon of the desired anomalous mass. The residual anomaly pattern on the depth $2170 \mathrm{~m}$ also reflects that one observed at depth $2015 \mathrm{~m}$ and the surface respectively. This depth $(2170 \mathrm{~m})$ marks the lower horizon of the desired anomalous mass. At depth $2325 \mathrm{~m}$, the residual anomaly pattern reflects that observed at depth $1860 \mathrm{~m}$ which is at variance with that observed on the surface. This shows that the projection has gone beyond the horizon of the anomalous mass [Blakerly, 1996]. At depth $2480 \mathrm{~m}$, the residual anomaly pattern also reflects the surface anomaly pattern. What this suggests is that there are still some contributions from deeper masses to the residual gravity anomaly observed on the surface. This validates the superposition principle observed in gravity investigation.

Seismic Horizon H4. The closure suggests possible depth horizon for hydrocarbon accumulation and the structural relief is between 2100 and $2700 \mathrm{~m}$. This lead on horizon $\mathrm{H} 4$ can be seen on the cross line 806-97-D-036

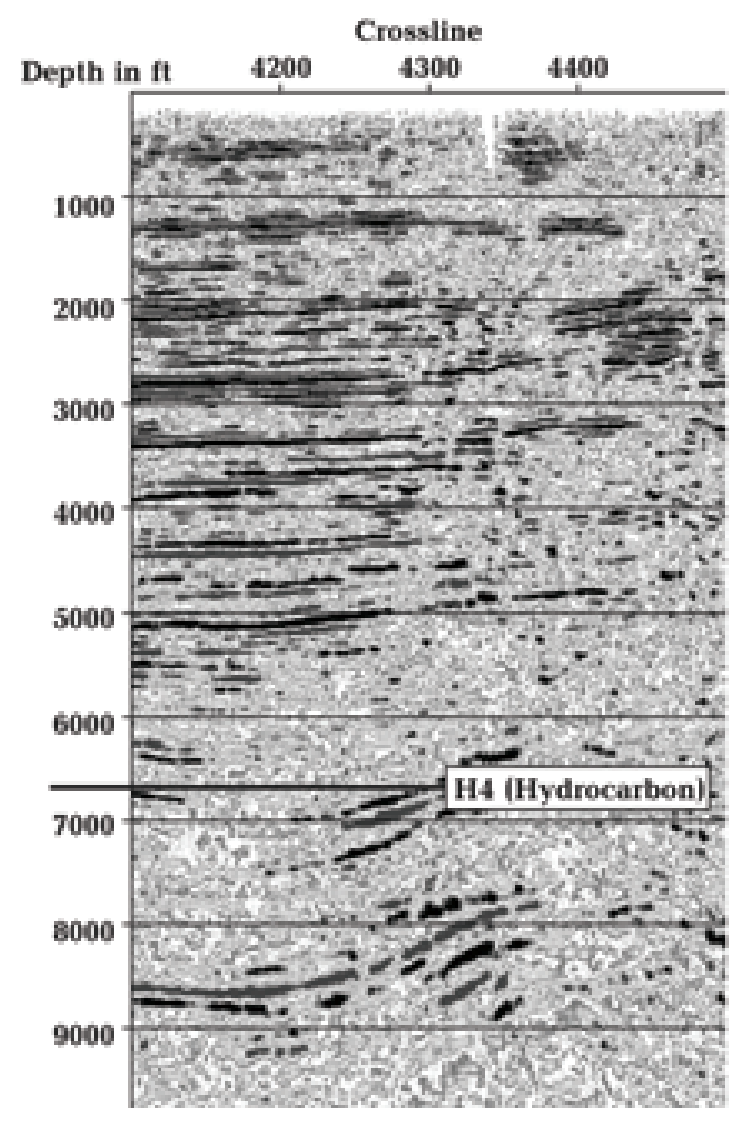

Fig. 6. Validation of gravity downward continuation using seismic reflection data (806-97-D-036).

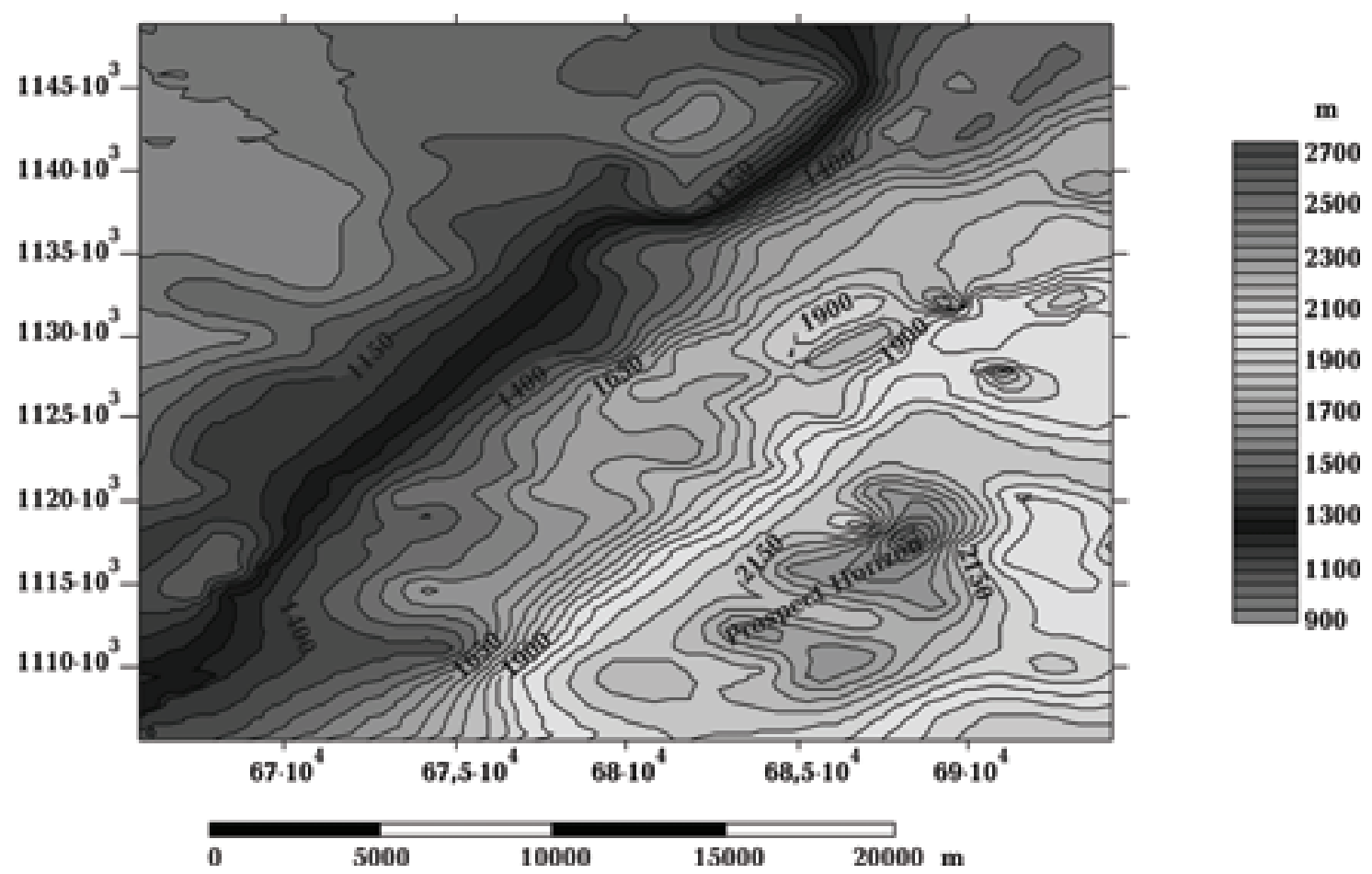

Fig. 7. Horizon H4 depth structure map (contour interval $50 \mathrm{~m}$ ). 
as shown in Fig. 6 . The section depth calibration (in feet) shows the horizon $\mathrm{H} 4$ lies at a depth between 6700 and $7150 \mathrm{ft}$ (2043-2180 m) respectively. The depth map (Fig. 7) shows the lead closure has a good fault trap for hydrocarbon accumulation at this horizon.

Gravity Result Validation using Reflection Seismic Results. The prospect depth lies between $2043 \mathrm{~m}$ and $2180 \mathrm{~m}$. This correlates with the result obtained from the isostatic residual gravity anomaly downward continuation obtained using the new model. The computation shows that the relative error percent is 1.37 and $0.46 \%$ respectively. The depth difference is not significant.

Relative error $\frac{d_{\text {seismic }}-d_{\text {gravity }}}{d_{\text {seismic }}} 100 \%, d_{\text {seismic }}$ - depth obtained from seismic, $d_{\text {gravity }}$ - depth obtained from gravity:

$$
\begin{aligned}
& ((2043-2015) / 2043) 100 \%=1.37 \% \text { (upper depth), } \\
& ((2180-22170) / 2180) 100 \%=0.46 \% \text { (lower depth). }
\end{aligned}
$$

Conclusion. In this paper, the integration of density log in the downward continuation has provided an improved method for downward continuation of potential field using Fourier transform. The minimization of the attenuation has helped to enhance the projected field in the determination of the depth of the anomalous mass through the elimination of short wave length. The model and real observation data test show that the new method provides a good result in downward continuation depth determination and should be adopted for basin analysis.

\title{
Predicting Depth of Mineral Deposit using Gravity-Density Downward Correlation by Fourier Transform
}

\author{
(C) E. E. Epuh, J. B. Olaleye, O. G. Omogunloye, 2016
}

\begin{abstract}
Residual gravity anomalies are the superposition of effects originating from several interfaces in the subsurface. In downward projection of the anomalies for the determination of the depth of the particular substructure which accounts for the bulk of the residual gravity anomalies on the plane can only be resolved with the aid of additional subsurface data such as density log. In this research, density log was used to determine the weighting density function, delineate the multiple layers and correlate with the gravity-density downward variation for predicting the mineral depth using the Fourier transform method. The results show that the projected residual gravity anomaly at depth between $2015 \mathrm{~m}$ and $2170 \mathrm{~m}$ depicts all the gravity features that are clearly associated with that on the original plane and also show minimal distortion of the shape of the anomalies. The anomalous mass lies between these depths. The downward continuation depths obtained from the gravity model were compared with that obtained from reflection seismic observation from the study area and the relative error percent were $1.37 \%$ and $0.46 \%$ respectively.

Key words: isostatic residual gravity anomaly, downward continuation, density log, attenuation, weighting density function.
\end{abstract}

\section{References}

Blakely R. J., 1996. Potential Theory in Gravity and Magnetics Application. Cambridge, United Kingdom: Cambridge University Press., 441p.

Byerly P. E., 1965. Convolution filtering of gravity and magnetic maps. Geophysics 30, 281-283. 
Clarke G. K. C., 1969. Optimum second derivative and downward continuation filters. Geophysics 34, 424-437.

Dean W. C., 1958. Frequency analysis for gravity and magnetic interpretation. Geophysics 23, 97-127.

Dobrin M. B., Savit C. H., 1988. Introduction to Geophysical Prospecting. $4^{\text {th }}$ Edition. Singapore: McGrawHill Book Co., 867 p.

Fuller B. D., 1967. Two-dimensional frequency analysis and design of grid operators. Mining Geophysics 2, 658-708.

Grant F. S., West G. F., 1987. Interpretation Theory in Applied Geophysics. Toronto: McGrawhill Book Company, $584 \mathrm{p}$.

Henderson R., 1960. A comprehensive system of automatic computation in magnetic and gravity interpretation. Geophysics 25, 569-585.

Mesko A., 1965. Some notes concerning the frequency analysis for gravity interpretation. Geophys. Prosp. 13, 475-488.

Peters L. J., 1949. The direct approach to magnetic interpretation and its practical application. Geophysics $14,290-320$. 